\section{Avaliação dos riscos para ocupação urbana: proposição metodológica baseada em geotecnologias}

\author{
Diego Rodrigues Macedo* \\ Antônio Pereira Magalhães Jr. **
}

Esta pesquisa se insere na atual discussão do GT População e Meio Ambiente, recentemente renomeado para População, Espaço e Ambiente. O estudo desenvolveuse, até o momento, sob dois aspectos principais: como foco, os riscos e vulnerabilidades da ocupação urbana; como metodologia, a utilização de indicadores censitários e sua integração a Sistemas Informativos Geográficos.

Neste contexto, o trabalho utiliza indicadores presentes no Censo Demográfico do IBGE, para a composição de um Índice de Vulnerabilidade da Ocupação Urbana IVOU e sua espacialização, utilizando como unidade de análise os setores censitários. O objetivo deste índice é contrapô-lo às condições físicas naturais, identificadas por meio de modelagem cartográfica, afim de estabelecer áreas prioritárias para a intervenção do poder público. Neste sentido, a pesquisa tem um enfoque metodológico, propondo uma análise mais detalhada da questão dos perigos e riscos para a ocupação urbana em grandes centros. No Brasil, cada estação chuvosa constitui-se em novo ciclo de desastres - atingindo um expressivo contingente populacional -, que estão relacionados, sobretudo, a dois processos naturais potencializados pela ocupação urbana desordenada: deslizamentos de encostas e enchentes.
Utilizou-se, como área-piloto, a microbacia do córrego da Abolição, localizada ao norte do município de Belo Horizonte, com uma área aproximada de $600.000 \mathrm{~m}^{2} \mathrm{e}$ um contingente populacional de cerca de 11.000 habitantes. Para o desenvolvimento dos trabalhos, consideram-se duas premissas básicas. A primeira refere-se ao meio físico, o qual engloba elementos formadores da paisagem que possuem fragilidades inerentes à ocorrência de processos naturais, colocando em perigo as populações locais. Nesta mesma linha de raciocínio, a segunda premissa considera que o risco se constitui na probabilidade de este perigo efetivamente atingir alguém. Assim, a metodologia desenvolvida segue estes dois pressupostos, contrapondo-se na análise final para buscar identificar as áreas prioritárias para a intervenção do poder público.

$\mathrm{Na}$ proposta metodológica para avaliação da fragilidade do meio físico, utilizouse como técnica cartográfica a análise booleana para identificar a suscetibilidade aos eventos analisados na microbacia. A segunda etapa metodológica, de caráter mais demográfico, correspondeu à elaboração do IVOU, utilizando-se três indicadores básicos: renda, escolaridade e número e faixa etária dos habitantes. Com isso, elaborou-se um mapa mesclando as duas concepções estudadas.

Em relação aos resultados do primeiro estudo, observaram-se dois problemas. $\mathrm{O}$ primeiro refere-se à forma como a metodologia de análise do meio físico foi concebida, apresentando dificuldade para replicá-la. Deve-se considerar que, em uma área maior, a diversidade de componentes do sistema tornará o modelo mais complexo, dificultando a interpretação das condicionantes do meio físico aos eventos estudados. Já o segundo diz respeito ao índice: foram utilizados poucos indicadores, além do fato de ser mais interessante compô-lo para todo o município de Belo Horizonte,

\footnotetext{
* Geógrafo, mestrando em Geografia pelo Instituto de Geociências - IGC, da Universidade Federal de Minas Gerais UFMG.

** Geógrafo, professor adjunto do Departamento de Geografia da Universidade Federal de Minas Gerais - UFMG. Doutor em Desenvolvimento Sustentável pela Universidade de Brasília - UnB.
} 
e, se possível, considerando uma faixa de variação entre 0 e 1.

Desta maneira, buscou-se, em um segundo momento, rever e desenvolver a metodologia, procurando simplificar a análise do meio físico e reelaborar o índice. Assim, utilizaram-se áreas maiores: em primeiro lugar a regional administrativa de Venda Nova, na qual a microbacia estudada se insere; e posteriormente todo o município de Belo Horizonte.

Para simplificar a análise do meio físico, adotaram-se critérios restritivos encontrados na legislação vigente, especificamente na Lei de Parcelamento, Uso e Ocupação do Solo de Belo Horizonte, a qual, para definir as áreas edificáveis e adensáveis, considera fatores naturais aqueles relativos a: áreas hidricamente sensíveis (nascentes), corpos d'água e declividade do terreno. Estes fatores resultaram em uma Compartimentação dos Fatores Físicos Naturais, visando o enquadramento das condicionantes do terreno, com base em parâmetros dinâmicos previamente definidos conforme as necessidades da área e os objetivos da pesquisa. Neste aspecto, cada município possui uma necessidade específica; portanto, em cada nova área de estudo, estes fatores podem variar.

O novo índice foi elaborado mantendose os setores censitários do IBGE como unidade espacial mínima. Foram utilizados, para a composição do novo IVOU, cinco indicadores: renda, escolaridade, serviços sanitários, densidade etária populacional e condição da habitação. Os indicadores de renda, escolaridade e serviços sanitários (coleta de lixo e de esgotos) foram considerados inversamente proporcional ao índice elaborado. A densidade etária populacional foi calculada atribuindo pesos ao total de habitantes do setor censitário. Para isso, levaram-se em conta dois aspectos: a capacidade motora e o tempo estimado de permanência no domicílio, para cada faixa etária, sendo o indicador considerado diretamente proporcional ao índice. A condição da habitação é uma característica disponível no censo por setor censitário. Neste caso, para os setores especiais subnormais, adotou-se o valor $1 \mathrm{e}$, para os demais, 0 (observa-se que grande parte dos setores em Belo Horizonte possui a condição comum). Os cinco indicadores tiveram valores padronizados e compreendidos entre 0 e 1 (com três casas decimais), de forma a tornar os resultados mais compreensíveis. $O$ índice temático foi obtido a partir da média simples dos seus indicadores.

Com as duas etapas metodológicas finalizadas, propôs-se integrar os dois resultados, valendo-se das facilidades operacionais das ferramentas de geoprocessamento. Decidiu-se empreender um processo de análise objetivando eleger as áreas prioritárias para intervenções no município de Belo Horizonte. Foi realizada uma análise cartográfica de multicritérios, atribuindo pesos às classes da Compartimentação dos Fatores Físicos Naturais e do IVOU. Por meio de técnicas de álgebra de mapas, chegou-se ao resultado final. Deste, foram excluídas as áreas não ocupadas, identificadas e disponibilizadas pela prefeitura de Belo Horizonte, mas que poderiam ter sido obtidas por uma interpretação manual de uma imagem ETM Landsat 7.

Cabe ressaltar, finalmente, que esta pesquisa resultou em uma monografia de graduação, uma monografia de pósgraduação lato sensu (especialização em geoprocessamento), um trabalho apresentado no XII Simpósio Brasileiro de Geografia Física Aplicada, um trabalho apresentado no II Seminário de Geoprocessamento da UFMG e uma exposição no workshop População e Meio Ambiente: novas metodologias de abordagem, realizado pelo GT.

Recebido para publicação em 06/03/2007. Aceito para publicação em 12/11/2007. 